\title{
BIOTRANSFORMATION OF ORANGE PEEL ESSENTIAL OIL BY A NATIVE PENICILLIUM SPECIES ISOLATED FROM ORANGE
}

\author{
Nadia M. Awny ${ }^{1}$, I.A. Abou-Elkhair ${ }^{1}$, M. A. Abdelaleem², Fawzia M. El- \\ nashaby $^{2}$, Yasmeen A. Hasanien ${ }^{2}$ \\ ${ }^{1}$ Botany Department, Faculty of Science, Zagazig University, Egypt. \\ ${ }^{2}$ Nuclear Research Center, Atomic Energy Authority, Cairo, Egypt. \\ Corresponding author: Abdelrazek_MD@yahoo.com
}

\begin{abstract}
Microbial biotransformation is a relevant strategy to obtain high added value natural compounds under controlled environmentally friendly conditions. In this research work, the use of agro-residues (orange peel oil) in the biotransformation of D-limonene by a native Penicillium italicumAUMC13045 species isolated from decayed orange was evaluated. The chemical analysis of water-steam distilled orange peel oil was determined by Gass Chromatography (GC) and D-limonene was shown to be the predominant constituent, representing $82.87 \%$ of the total content. It was investigated that the highest $\alpha$-terpineol yield was obtained by Malt Yeast Broth (MYB) medium at the second day after the first addition of orange peel oil. The highest $\alpha$-terpineol selectivity obtained when bioconversion media inoculated with fungal conidia at the early stage of the exponential growth. The investigated samples gave higher $\alpha$-terpineol yield when extracted by mixture of (1:1) diethyl ether and pentane.
\end{abstract}

\section{Introduction}

In the last years, there has been an increasing trend towards efficient utilization and value addition of agro-industrial residues. Orange fruits have been part of human diet for ages due to its nutritional and medicinal values. But consumption of orange fruits generates orange peel wastes that could bring about environmental pollution if not properly handled (Ezejiofor et al., 2011).

On the other hand, the application of citrus peel waste in bioprocesses provides another new substrates and it helps to display the solution of the pollution problems where the direct disposal of agro-industrial residues as 
a waste on the environment represents an important loss of biomass, which could be bio converted into different metabolism, with a higher commercial value (Pandey et al., 2000). Unlike traditional chemical processes, which require extreme temperatures and pressures, microbial conversions take place under mild conditions and, in some instances, the products are formed stereoselectively (Aissou $\boldsymbol{e t} \boldsymbol{a l}$. , 2017).

Essential oils considered as the most significant by-product usually obtained from citrus peel and make up the major sector of the world production of essential oils (Tirado et al., 1995). $\mathrm{R}-(+)-$ limonene, is the main compound in orange essential oil, it represents more than $90 \%$ and in enantiomerically pure form, thus being an inexpensive citrus byproduct available in bulk amounts (Adams et al., 2003).

An interesting end product resulting from the bioconversion of limonene is the monoterpene alcohol $\alpha$-terpineol. Bioconversion of limonene to $\mathrm{R}$ $(+)$ - $\alpha$-terpineol has been described, using a wide range of microorganisms as catalysts: Penicillium digitatum DSM 62840 (Abraham et al., 1986;Adams et al., 2003), Pseudomonas gladioli (Cadwallader and Braddock, 1992), Aspergillus cellulosae M-77 (Noma et al., 1992), Bacillus stearothermophillus BR388 (Chang and Oriel, 1994), Fusarium oxysporum 152B (Bicas et al., 2010), Pleurotus sapidus (Onken and Berger, 1999), Aspergillus niger (ATCC 16404, ATCC 9642 and ATCC 1004 strains) (Rottava et al., 2010). In all cases, the process is highly enantiospecific (Bicas et al., 2009), but the product concentration depend on the reaction conditions.

$\alpha$-terpineol has a significantly higher added value than limonene, it is considered to be a safe additive, because it has a characteristic aroma of lavender, which is commonly used as fragrance in the industry of perfumes, fragrances, cosmetics and toiletries (Fisher and Phillips, 2008). It is also used in the pharmaceutical industry as an antifungal and disinfectant product (Jun and Jeong, 2006), and in the food industry as a preservative due to its antimicrobial and antioxidant properties (Bicas $\boldsymbol{e t}$ al., 2010).

Furthermore $\alpha$-terpineol have shown biological activity in vivo against certain types of tumor, not only preventing the formation or progression of the cancer, but also regressing existing malignant tumors (Jun and Jeong, 2006). These characteristics greatly enhance the industrial interest in such compounds and, for this reason; the biotransformation process has emerged as an attractive alternative for the conversion of limonene.

To increase the commercial value of the orange peel oil it would be of interest to be able to convert its predominant content, D-limonene, into more valuable compounds, such as $\alpha$-terpineol. Thus, this paper study the 
biotransformation of orange peel oil using both Penicillium spp. isolated from orange and discusses the influence of many culture conditions on the conversion capacity.

\section{Materials and Methods \\ Materials}

Orange fruits (citrus sinensis) at mature stage, were obtained at 2016 2017 from local market, Sharqia Governorate, Egypt. Orange fruits were peeled manually, to obtain the tested orange peels. D-Limonene standard and $\alpha$-terpineol standard were purchased from Fluka ${ }^{\mathrm{TM}}$, Sigma-Aldrich, Switzerland. Diethyl ether and Ethyl acetate were purchased from SDFCL ${ }^{\mathrm{TM}}$, Mumbai, India. Pentane (Alkan $\mathrm{C}_{5}$ ), were purchased from Merck, Germany.

\section{Microbiological media}

Potato Dextrose Agar (PDA): $2 \%$ glucose, $0.4 \%$ potato extract, $1.5 \%$ agar. Malt Extract Agar (MEA): 2\% malt extract, 0.1\% peptone, 2\% glucose, $1.5 \%$ agar. Yeast Glucose Agar (YGA): $0.3 \%$ yeast, $2 \%$ malt extract, $0.1 \%$ peptone, $2 \%$ glucose, $1.5 \%$ agar. Czapek's Dox Agar (CDA): $0.2 \%$ Sodium nitrate, $0.05 \%$ Potassium chloride, $0.05 \%$ Magnesium glycerophosphate, $0.001 \%$ Ferrous sulphate, $0.035 \%$ Potassium sulphate, $3 \%$ Sucrose, $1.5 \%$ agar. Broth was made without agar addition. Distilled water was added to each medium up to $1 \mathrm{~L}$.

\section{Extraction of orange peel oil}

The essential oils of orange was extracted by applying water/steam distillation method using a Clevenger-type apparatus, then the essential oils yield was measured according to Guenther (1961). Orange fruits were peeled off carefully, to avoid any damage of oil glands. The separated part of orange (flavedo) was employed in round flask, deionized water in another connected flask was added and then boiled. The apparatus of water/steam distillation is set-up. The boiling time was 120 - 160 min., the extracted volatile oils was collected, dried over anhydrous sodium sulphate, put in opaque glass bottles and kept at $-20{ }^{\circ} \mathrm{C}$ until needed.

\section{Isolation and identification of isolated fungus}

The native fungal species were isolated from decayed oranges fruits collected from different market places in Egypt, direct isolation of the fungi has been done by taking direct smear of spores from the surface of the fruit and placed on petri dish plates contained PDA medium. Petri dishes were incubated at $25 \pm 2{ }^{\circ} \mathrm{C}$ for 5 days. The tested fungi were cultivated on media containing the orange peel oil as the sole carbon source to study the ability of fungi to metabolize orange oil. 
The detected fungi were carefully isolated into pure cultures of PDA in slants and incubated for 7 days at $28^{\circ} \mathrm{C}$. The purified cultures were prepared into mounts in microscopic slides by placing portion of mycelial growth carefully picked with the aid of sterile inoculating needle in a drop of lactophenol cotton blue. The microscopic slide was examined under the microscope for morphology. The fungal isolates were identified by comparing their morphology and characteristics with descriptions given by (Samson and Pitt, 2000).

Native Penicillium spp. isolate selected for biotransformation in further experiments was identified by Mycological Center, faculty of science, Assiut University (AUMC). Identification was done morphologically based on macro- and microscopic characteristics and descriptions given by Pitt (1979) and Domsch et al. (2007) Domsch et al. (2007). It is close to Penicillium italicum Wehmer. Thus, the fungal strain of Penicillium sp. was identified as Penicillium italicum AUMC13045 (Figure 1).

\section{General process of limonene biotransformation at laboratory scale.}

Biotransformation experiments by shaken liquid cultures of a native Penicillium italicum AUMC13045 was run according to Marostica- Jr and Pastore (2007) with some modifications concerning substrate and sampling time, where the oil concentration added was $50 \mu \mathrm{l}$ each $12 \mathrm{~h}$ at total addition $300 \mu \mathrm{l}$. The mold was cultivated in $250 \mathrm{ml}$ flasks, filled with $150 \mathrm{ml}$ of sterile liquid media. The culture media was inoculated with $1 \mathrm{ml}$ of fungi spore suspension and pre-incubated at $27^{\circ} \mathrm{C}$ for $72 \mathrm{~h}$ with agitation of $150 \mathrm{rpm}$, using an orbital shaker.

After pre-incubation, biotransformation was initiated with the addition of $50 \mu \mathrm{l}$ of orange peels oil (under sterile condition) two subsequent addition of $50 \mu \mathrm{l}$ orange oil every $24 \mathrm{~h}$ were performed. Chemical blanks were performed in all biotransformation experiments (media containing only orange peels oil without mycelium) to ensure the absence of chemical transformation reactions. Twenty-four, 48 and $72 \mathrm{~h}$ after the addition of orange peels oil, $5 \mathrm{ml}$ samples were taken for extraction and analysis using GC analysis.

\section{Comparison of different culture broth}

Biotransformation experiments were carried out in liquid media, using PDB, YGB and MYB under the environmental conditions. Orange peel oil was added at a final concentration of $150 \mu \mathrm{l}(50 \mu \mathrm{l} / 24 \mathrm{hr})$. Kinetics of microbial transformation was monitored at $0,24,48$ and $72 \mathrm{~h}$ after adding the substrate. The culture medium with the highest bioconversion values was selected for evaluating additional biotransformation parameters. 


\section{Evaluation of the microorganism growth phases on orange oil biotransformation}

The bioassays were carried out in $250 \mathrm{~mL}$ flasks, containing $150 \mathrm{~mL}$ of sterile liquid medium. Culture media were inoculated with $1 \mathrm{~mL}$ of spore suspension of Penicillium italicam AUMN13045 and pre-incubated at $27^{\circ} \mathrm{C}$ for $24,72,120,168$ and $216 \mathrm{~h}$, according to the lag, early exponential, media exponential, final exponential and stationary phases respectively, with an agitation of $150 \mathrm{rpm}$ using an orbital shaker. Once fungal strain reached the corresponding phase, orange peel oil was added to the culture medium at a final concentration of $150 \mu$ l. The microbial biotransformation kinetics for each biotransformation was monitored at 0 , 24, 48 and $96 \mathrm{~h}$ after the reaction. The growth phase with the highest bioconversion was selected for evaluating further parameters (Prieto $\boldsymbol{e t}$ al., 2011).

\section{Influence of solvents on the bioconversion process}

Ethyl acetate and mixture of diethyl ether and pentane $(1: 1, \mathrm{v} / \mathrm{v})$ were used to choose the appropriate solvent used in extraction. After 24, 48, and $72 \mathrm{hr}$ from the addition of orange peels oil, $5 \mathrm{ml}$ samples were taken for extraction and analysis.

\section{Analysis of samples by GC}

At the end of each bioconversion experiment, $5 \mathrm{ml}$ cultural filtrate were extracted by diethyl ether and pentane $(1: 1, \mathrm{v} / \mathrm{v})$ and identified by gas chromatography GC (Marostica- Jr and Pastore, 2007). GC analysis was performed using Perkin Elmer Auto system XL equipped with flame ionization detector (FID). A fused silica capillary column DB - $5(60 \mathrm{~m} \times$ $0.32 \mathrm{~mm}$, i.d.) was used. Helium was used as the carrier gas, at flow rate $1.1 \mathrm{ml} / \mathrm{min}$. The injector and detector temperatures were 220 and $250^{\circ} \mathrm{C}$, respectively. The injector and detector temperatures were 240 and $250^{\circ} \mathrm{C}$, respectively. The retention indices (Kovats index) of the separated volatile compounds were calculated with hydrocarbons $(\mathrm{C} 8-\mathrm{C} 22$, Aldrich Chemical Co.) as references.

The reduction in the limonene area (at each sampling time) between blank and sample experiments was used in the calculation of limonene bioconversion (\%) according to Demyttenaere et al. (2001) as follows:

Limonene bioconversion $(\%)=\frac{(\text { area of limonene in a blank }- \text { area of limonene in a sample })}{\text { area of limonene in a blank }} \times 100$

Where, the $\alpha$-terpineol production was followed using GC analysis in all culture extracts to calculate the percentage of limonene bioconversion (The major monoterpenes components of orange peel essential oil were dlimonene representing $82.87 \%$ ). 
Then, the yield of $\alpha$-terpineol calculated as the amount of $\alpha$-terpineol produced as compared with the amount of limonene added.

\section{Results}

\section{Isolation and identification of fungal isolates}

The fungal isolates that possess the ability to metabolize orange peel oil has been selected and identified in our study. Where, the resulting colonies on PDA were growing with woolly in texture, initially white and become green while reverse white to yellowish (Figure 1A). The hyphae under microscope were septate and hyaline, conidiophores were unbranched and microconidia were abundant, thin-walled, hyaline and ovoid (Figure 1C).

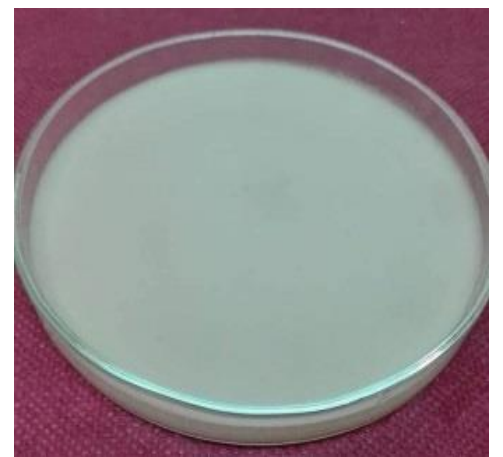

A

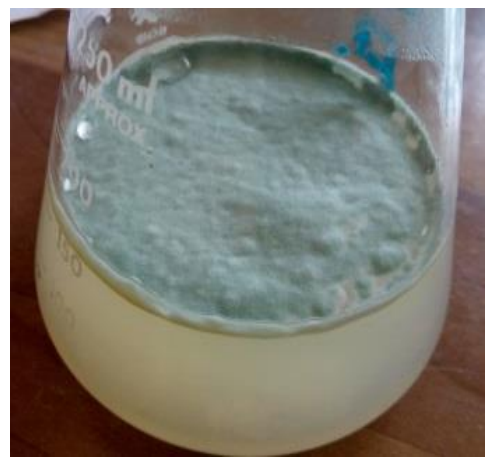

B

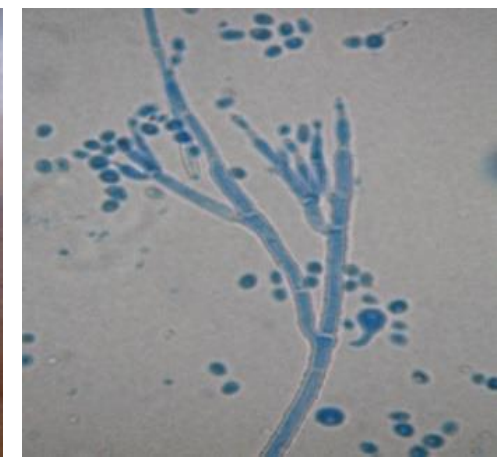

C

Fig. 1. Fungal isolates on PDA (A), fungal isolates on PDB (B) and fungal isolates under microscope high power magnification (X400) (C).

Our study in a harmony with Demyttenaere et al. (2001) and (2003), who found that the most interesting strains for the bioconversion of (R)(+)-limonene to $\alpha$-terpineol, were Penicillium digitatum strains.

\section{Comparison of different cultures broth and their compositions}

The biotransformation of orange peel oil by Penicillium italicam AUMC13045 were compared using three different media (PDB, YGB and MYB). The yields of $\alpha$-terpineol obtained from samples 1,2 and 3 taken after 24,48 and $72 \mathrm{~h}$ respectively, after first addition of orange oil are displayed in Table (1). Our obtained data clarify that MYB media gives the highest yield of bioconversion product in all samples taken after different time from the first addition. In addition, the bioconversion process is highly done in MYB medium then YGB and PDB, respectively. In former experiments (Adams et al., 2003) found that the most interesting media for the bioconversion of $(+)$-limonene, were MYB media. These results are similar to that obtained by (Badee $\boldsymbol{e t}$ al., 
2011; Prieto et al., 2011). On the other hand, our findings are in the line with Bowen (1975) who mentioned that Penicillium italicum converted more d-limonene than Penicillium digitatum did. All experimental data figure out that Penicillium italicam AUMC13045 has the ability to utilize orange essential oil as a soul carbon source in medium supplemented with orange essential oils instead of glucose as a natural carbon source especially when added sequentially (data not shown), in addition shaking flasks was an essential point in all experiments. This finding was in the same with Demyttenaere and De Kimpe (2001) and (Chen and Reese, 2002).

Table 1. Effect of different media type on the $\alpha$-terpineol production

\begin{tabular}{lccccccccc}
\hline & \multicolumn{3}{c}{ Sample 1 } & \multicolumn{3}{c}{ Sample2 } & \multicolumn{3}{c}{ Sample 3 } \\
\cline { 2 - 9 } & PDB & YGB & MYB & PDB & YGB & MYB & PDB & YGB & MYB \\
\cline { 2 - 9 } Extract Content (\%) & & & & & & & & & \\
Unconverted Limonene & 38.03 & 44.17 & 30.83 & 20.78 & 31.94 & 7.84 & 47.05 & 53.27 & 38.95 \\
Produced $\alpha$-terpineol & 30.24 & 27.39 & 34.61 & 49.03 & 40.32 & 86.70 & 16.89 & 12.01 & 22.34 \\
Other products & 31.73 & 28.44 & 34.56 & 30.19 & 27.74 & 23.46 & 36.06 & 34.72 & 38.71 \\
Biotransformation (\%) & & & & & & & & & \\
$\alpha$-terpineol biotransformation & 22.73 & 20.28 & 37.41 & 62.16 & 43.99 & 83.27 & 10.22 & 7.03 & 15.16 \\
Yield of $\alpha$-terpineol & 36.49 & 33.05 & 41.76 & 59.16 & 48.65 & 82.90 & 20.38 & 14.6 & 26.95 \\
\hline
\end{tabular}

\section{Evaluation of the effect of the growth phases on orange oil biotransformation}

In these experiments, orange oil was added in the culture medium in different growth phases of the microorganisms, its biotransformation was monitored every $24 \mathrm{hr}$ for $72 \mathrm{hr}$. In all cases Penicillium italicam AUMC13045 cells produced $\alpha$-terpineol. However, the highest $\alpha$ terpineol selectivity $(69.87 \%)$ was obtained when orange oil was added in the early exponential growth phase $(72 \mathrm{hr})$. $\alpha$-terpineol production decreased between $50 \%$ and $60 \%$ in the culture medium when orange oil was added in different growth phases. These results illustrated in Figure (2). Tan et al. (1998) found that limonene biotransformation only occurs between early phase and the half of the exponential phase. These data are in agreement with the findings of Prieto et al. (2011). 


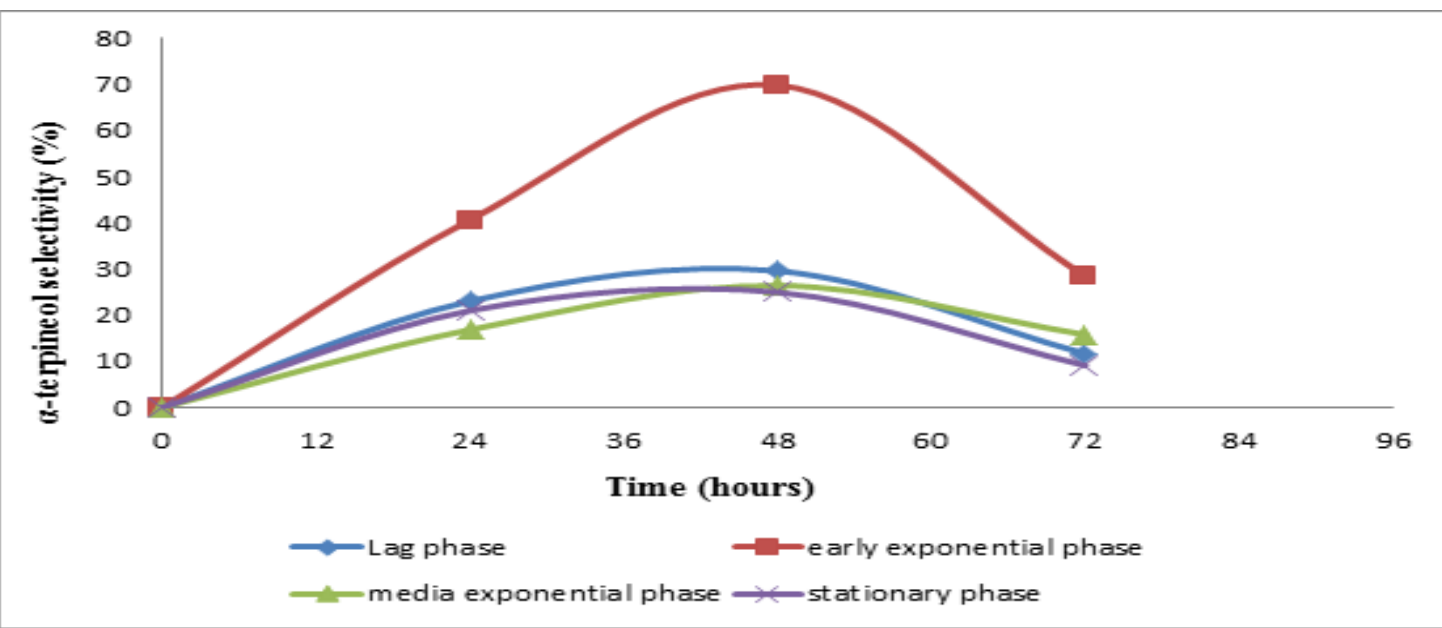

Fig. 2. Effect of the addition orange oil in different growth phases of Penicillium italicam AUMC13045 on the $\alpha$-terpineol selectivity

\section{Influence of solvents on the $\alpha$-terpineol yield}

The samples obtained by bioconversion of orange oil were extracted with two types of solvent, to select the best solvent for extraction. From results displayed in Table (2), the yield of $\alpha$-terpineol resulted from biotransformation of orange oil using culture of Penicillium italicum AUMC13045 was 72.92 and $3.52 \%$ for products extracted by diethyl ether and pentane mixture and ethyl acetate respectively. From previous results it can be concluded that the yield of $\alpha$-terpineol was increased when the mixture of diethyl ether and pentane were used in the extraction of products and remaining substrate was clearly higher than that obtained when ethyl acetate was using as extraction solvent. Our data are in the same line with Tan et al. (1998), Demyttenaere et al. (2001) and Marostica- Jr and Pastore (2007) who extracted all experimental samples with diethyl ether and immediately subjected to GC analysis.

Table 2. Effect of types of solvents on the bioconversion of Penicillium italicam AUMC13045

Extract content (\%)

Unconverted Limonene Diethyl ether : Pentane

Produced $\alpha$-terpineol

Other products

$(1: 1, \mathrm{v} / \mathrm{v})$

19.84

60.43

19.73

Ethyl acetate

Biotransformation (\%)

Total biotransformation

80.16

44.27

2.92

Bioconversion

57.95

55.73

Yield of $\alpha$-terpineol

72.92

10.26

3.52 


\section{Discussion}

The components of essential oil are important, as their qualitative and quantitative composition determines the characteristics of the oils. In all former studies, it was found that on the one hand, most of the identified substances of orange peel oil are monoterpene hydrocarbons, and limonene is undoubtedly the major component of monoterpenes (Djenane, 2015;Kamal et al., 2011;Njoku and Evbuomwan, 2014;Tao et al., 2009). Moufida and Marzouk (2003) confirmed that the orange essential oil consists mainly of limonene. This compound varies between $68 \%-98 \%$. Limonene is a colorless liquid hydrocarbon classified as a monocyclic terpene. The more common $\mathrm{d}$-isomer possesses a strong smell of oranges. It is used in chemical synthesis as a precursor to oxygenated compounds that has a significantly higher added value than limonene (Fisher and Phillips, 2008).

Limonene can be transformed into $\alpha$-terpineol using strains from different fungi. Microorganisms and their enzymes have proven to be versatile biocatalysts (Jones et al., 1993) and are extensively used for biotransformations of various terpenoids (Trudgill, 1990). A large variety of enzymes occur in several microorganisms (such as bacteria, yeast and fungi) which are effective in biotransformations of various terpenoids and can be used in vivo. In addition, whole cells are generally much less expensive compared to purified enzymes, and, in some cases, enzymes are more stable within the cell, thus extending the life of the biocatalyst (Knox and Cleffe, 1984). Another advantage of using whole cells is that the addition of purified cofactor is not required, since it already contained within the cell.

The medium composition usually displays an important role in biotransformation processes, being one of the main factors responsible for alterations in yield (Adams et al., 2003). Prieto et al. (2011) showed that the culture medium can affect both specificity and product concentration. Malt Yeast Broth (MYB) was the most interesting media for the bioconversion of d-limonene to $\alpha$-terpineol (Adams et al., 2003; Badee $\boldsymbol{e t}$ al., 2011;Prieto et al., 2011).

Undoubtedly, the low biotransformation of the YGB and PDB media was possibly due to a catabolic repression like mechanism by a high glucose concentration, which led to the decrease in the use of limonene as a source of carbon and energy (Bicas et al., 2009). Regarding to the composition of media previously illustrated, the highest concentration of glucose was found in PDB medium (20\%) (Bridson, 2006) compared to other media where, YBG and MYB contain $2 \%$ and $1 \%$, respectively (Tan et al., 1998). Similar effects have been reported by Bowen (1975) 
and Duetz et al. (2003) who found additional carbon sources (higher concentration of glucose) inhibited the conversions of fungal strains. Another explanation is the stability of D-limonene under the acidic conditions, as reported by Adams et al. (2003). It is well known that the $\mathrm{pH}$ of PDB is 5.6, but it is 6.1 in MYB, so the acidity is higher in PDB than MYB medium, which negatively affected the bioconversion of Dlimonene in PDB medium.

On the other hand, the toxicity of substrate is one of the major factors that influence the behavior of the cells in organic aqueous multiphase systems. Our study represents that the orange essential oil was added sequentially thus, the substrate concentration raised gradually meanwhile cells have the ability to adapt the composition of the cell membrane. All these procedures happened in the resting state of fungal stain (de Carvalho et al., 2004). Meanwhile, shake flasks are simple and efficient for screening fungal strain, substrates and reaction conditions rapidly and inexpensively (Chen and Reese, 2002).

It is known, in most enzymatic reactions, that the reaction product concentration affects the velocity of reaction, hence affecting the final product; so, the bioconversion rate is not stable over all the reaction time. So, some authors have reported that there is a correlation between best time of fungal growth and best bioconversion yield (Adams et al., 2003). As shown in Figure (2), it could be summarized that the best time for the highest $\alpha$-terpineol concentration was the second day after the first addition of the orange oil (the fifth day of fungal growth).

Our finding has also proven that, the best time for fungal growth was the exponential growth phase. Our obtained data were in the same trend with Prieto et al. (2011) who detected that the highest production rat of $\alpha$ terpineol rate was obtained when limonene was added in the early exponential growth phase (72hr). Furthermore, the growth phase effect on limonene bioconversion has been evaluated by Tan et al. (1998) using Penicillium digitatum NRRL 1202. The authors found that limonene biotransformation only occurs between early phase and the half of the exponential phase and the highest production of $\alpha$-terpineol was obtained by a sequential substrate induction. Meanwhile, Cadwallaer et al. (1989) bioconverted D-limonene to $\alpha$-terpineol and perillic acid using Pseudomonas gladioli. They found that the concentration of $\alpha$-terpineol in the fermentation flasks increased to a maximum at day 4 and decreased by about $12 \%$ at day 10 . They attributed this decrement to evaporation of $\alpha$-terpineol. 


\section{Conclusion}

The previously data summarized that the best fungal medium yielding $\alpha$ terpineol, used in bioconversion process by Penicillium italicam AUMC13045, was MYB (82.90 \%) compared to other media. Orange essential oil could be used as a soul carbon source when added sequentially. Furthermore, the highest $\alpha$-terpineol selectivity $(69.87 \%)$ was obtained when orange oil was added in the early exponential growth phase (second day after the first addition of the orange oil). Solvents used in extraction process was suggested that diethyl ether: pentane $(1: 1, \mathrm{v} / \mathrm{v})$ as the best solvent could be used in bioconversion process.

\section{References}

Abraham, W. R.,Stumpf, B., and Kieslich, K. (1986). Microbial transformations of terpenoids with 1-p-methene skeleton. Applied Microbiology and Biotechnology journal, 24, 24-30.

Adams, A.,Demyttenaere, J. C. R., and De Kimpe, N. (2003). Biotransformation of (R)-(+)- and (S)-(-)-limonene to $\alpha$-terpineol by Penicillium digitatum investigation of the culture conditions. Food Chemistry, 80, 525-534.

Aissou, M.,Chemat-Djenni, Z.,Yara-Varon, E.,Fabiano-Tixier, A. S., and Chemat, F. (2017). Limonene as an agro-chemical building block for the synthesis and extraction of bioactive compounds. Comptes Rendus Chimie, 20, 346-358.

Badee, A. Z. M.,Helmy, S. A., and Morsy, N. F. S. (2011). Utilisation of orange peel in the production of a-terpineol by Penicillium digitatum (NRRL 1202). Food Chemistry, 126, 849-855.

Bicas, J. L.,Quadros, C. P.,Néri-Numa, I. A., and Pastore, G. M. (2010). Integrated process for co-production of alkaline lipase and R-(+)-a-terpineol by Fusarium oxysporum. Food Chemistry, 120, 452-457.

Bicas, L. J.,Fontanille, P.,Pastore, G. M., and Larroche, C. (2009). A bioprocess for the production of high concentrations of R-(+)-aterpineol from R-(+)-limonene. Process Biochemistry journal, 45 (4), 481-486.

Bowen, E. R. (1975). potential by-products from microbial transformation of D-limonene Proceedings of the Florida state Horti cultural Society, Miami Beach, 304-308.

Bridson, E. Y. (2006). The oxoid manual , 9 th Ed. Wade Road, Hampshire RG24 8PW, England 
Cadwallader, K. R., and Braddock, R. J. (19 .(92Enzymatic Hydration of (4R)-(+)-Limonene to (4R)-(+)- $\alpha$-Terpineol. Developments in Food Science, 29, 571-584.

Cadwallaer, K. R.,Braddock, R. J.,Parish, M. E., and Higgins, D. P. (1989). Biconversion of (+)-Limonene by Pseudomonas gladioli. Journal of Food Science, 54 (5), 1241-1245.

Chang, H. C., and Oriel, P. (1994). Bioproduction of perillyl alcohol and related monoterpenes by isolates of Bacillus stearothermophilus. Journal of Food Science, 59, 660-662.

Chen, A. R. M., and Reese, P. B. (2002). Biotransformation of terpenes from Stemodia maritima by Aspergillus niger ATCC 9142. Phytochemistry, 59, 57-62.

de Carvalho, C. C. C. R.,Cruz, A.,Angelova, B.,Fernandes, P.,Pons, M. N., and Pinheiro, H. M. (2004). Behaviour of Mycobacterium sp NRRL B-3805 whole cells in aqueous, organic-aqueous and organic media studied by fluorescence microscopy. Applied Microbiology and Biotechnology, 64, 695-701.

Demyttenaere, J., and De Kimpe, N. (2001). Biotransformation of terpenes by fungi study the pathways involved Journal of Molecular Catalysis , B Enzyme,, 11, 265-270.

Demyttenaere, J. C. R.,Belleghem, K. V., and Kimpe, N. D. (2001). Biotransformation of (R)-(+)- and (S)-(-)-limonene by fungi and the use of solid phase microextraction for screening. Phytochemistry.208-199,57,

Djenane, D. (2015). Chemical Profile, Antibacterial and Antioxidant Activity of Algerian Citrus Essential Oils and Their Application in Sardina pilchardus. Foods, 4, 208-228.

Domsch, K. H.,Gams, W., and Anderson, T. H. (2007). Compendium of soil fungi. . 2nd Edition IHW-Verlag Eching (672 pages.(

Duetz, W. A.,Bouwmeester, H.,van Beilen, J. B., and Witholt, B. (2003). Biotransformation of limonene by bacteria, fungi, yeasts, and plants. Applied Microbiology and Biotechnology journal, 61, 269.277-

Ezejiofor, T. I. N.,Eke, N. V.,Okechukwu, R. I.,Nwoguikpe, R. N., and Duru, C. M. (2011). Waste to wealth: Industrial raw materials potential of peels of Nigerian sweet orange (Citrus sinensis). African Journal of biotechnology, 10 (33), 6257-6265.

Fisher, K., and Phillips, C. (2008). Potential antimicrobial uses of essential oils in food: is citrus the answer?. Food Science and Technology, 19 (3), 156-165. 
Guenther, E. (1961). The essential oils. (D. V. N. Company, ed.), Vol. Vol. I, III, IV, 4th Ed. , New Jersy. Tornto, New York, London.

Jones, K. H.,Trudgill, P. W., and Hopper, D. J. (1993). Metabolism of p-Cresol by the Fungus Aspergillus fumigatus. Applied and environmental microbiology, 59 (4), 1125-1130.

Jun, M., and Jeong, W. S. (2006). Health promoting properties of natural flavours substances. Food Science and Biotechnology, 15 (3), 329-339.

Kamal, G. M.,Anwar, F.,Hussain, A. I.,Sarri, N., and Ashraf, M. Y. (2011). Yield and chemical composition of Citrus essential oils as affected by drying pretreatment of peels. International Food Research Journal, 18 (4), 1282-1290.

Knox, T., and Cleffe, K. (1984). Synthesis of long-chain estersin a loop reactor system using a fungal bound enzyme. Process Biochemistry, 9, 188-192.

Marostica- Jr, M. R ,.and Pastore, G. M. (2007). Production of R-(+)a-terpineol by the biotransformation of limonene from orange essential oil, using cassava waste water as medium. Food Chemistry, 101, 345-350.

Moufida, S., and Marzouk, B. (2003). Biochemical characterization of blood orange, sweet orange, lemon, bergamot and bitter orange. Phytochemistry, 62, 1283-1289.

Njoku, V. I., and Evbuomwan, B. O. (2014). Analysis and Comparative Study of Essential Oil Extracted from Nigerian Orange, Lemon and Lime Peels. Greener Journal of Chemical Science and Technology, 1 (1), 6-15.

Noma, Y.,Yamasaki, S., and Asakawa, Y. (1992). Biotransformation of limonene and related compounds by Aspergillus cellulosae. The International Journal of Plant Biochemistry, 31 (8), 1-3.

Onken, J., and Berger, R. G. (1999). Effects of R-(+)-limonene on submerged cultures of the terpene transforming basidiomycete Pleurotus sapidus. Journal of Biotechnology, 69 (2-3), 163-168.

Pandey, A.,Soccol, C. R.,Nigam, P.,Brand, D.,Mohan, R., and Roussos, S. (2000 .(Biotechnological potential of coffee pulp and coffee husk for bioprocess. Biochemical Engineering Journal, 6, 153-162.

Pitt, J. I. (1979). Thec genus Penicillium and its teleoomorphic states Eupenicillium and Talaromyces. Academic Press, London- New York,pp634. 
Prieto, S. G. A.,Pereap, V. J. A., and L.C.C., O. (2011). Microbial biotransformation of (R)-(+)-Limonene by Penicillium digitatum DSM 62840 for producing (R)-(+)-Terpineol. VITAE, 18, 163-172.

Rottava, I.,Toniazzo, G.,Cortina, P. F.,Martello, E,.Grando, C. E., and Lerin, L. A. (2010). Screening of microorganisms for bioconversion of (-)- $\beta$-pinene and R-(+)-limonene to a-terpineol. . Journal of Food Science and Technology, 43 (7), 1128-1131.

Samson, R. A., and Pitt, J. I. (2000). Integration of Modem Taxonomic Methods for Penicillium and Aspergillus Classification. Harwood Academic Publishers, Amsterdam, 1, 9-49.

Tan, Q.,Day, D. F., and Cadwallaer, K. R. (1998). Bioconversion of (R)-(+)-limonene by $P$. digitatum (NRRL 1202). Process Biochemistry journal, 33 (1), 29-37.

Tao, N. G.,Liu, Y. J., and Zhang, M. L. (2009). Chemical composition and antimicrobial activities of essential oil from the peel of bingtang sweet orange (Citrus sinensis Osbeck). International Journal of Food Science and Technology.1286-1281,44,

Tirado, C. B.,Stashenko, E. E.,Combariza, M. Y., and Mar- tinez, J. R. (1995). Comparative study of Colombian citrus oils by highresolution gas chromatography and gas chromatography-mass spectrometry. Journal of Chromatography A, 697, 50.513-1

Trudgill, P. W. (1990). Microbial metabolism of monoterpenes recent developments. Biodegradation, 1 (2-3), 93-105. 


\section{التحول الميكروبى للزيت العطرى لقشور البرتقال بإستخدام عزلة بنسيليوم محلية معزولة من البرتقال} نادية محمد عونى 1 - إبراهيم أحمد أبو الخير1 1 ـ محمد عبد الرازق عبد العليم² ـ فوزية محمد النشابى2 -

$$
\begin{aligned}
& 1 \text { قسم النبات ـ كلية العلوم - جامعة الزقازيق } \\
& 2 \text { مركز البحوث النورية - هيئة الطاقة الذرية المصرية }
\end{aligned}
$$

أصبحت عملية التحول الميكروبى من التقنيات المتطورة و الحديثة للحصول على مركبات طبيعية ذات قيمة غذائية و علاجية عالية من مخلفات غذائية وصناعية تحدث ضررا بالغا بالبيئة. لذلك تهدف هذا الدراسة لإستخدام المخلفات الزراعية الصناعية (الزيوت العطرية لقشور ثمار البرتقال) فى عمليات التحول الميكروبى لمركب الـ (دىـ ليمونين) ـالمركب السائد فى الزيت العطرى لثمار البرتقال - وذلك بإستخدام عزلة بنيسلسوم محلية معزولة من ثمار البرتقال المتحللة. تم تحليل الزيت العطرى المستخلص بالتقطير البخارى بإستخدام التحليل الكروماتوجر افى الغازى حيث تم تقدير مركب الـ دىـ ليمونين المركب السائد فى الزيت العطرى بنسبة 82.87\% من المحتوى الكلى للزيت. أثبتت الدراسة أن أعلى إنتاجية لمركب الألفا تربينيول بإستخدام بيئة المولت ومستخلص الخميرة السائلة وذللك بعد ثانى يوم من إضافة الزيت العطرى للبيئة الفطرية. كذلك كانت أعلى إنتاجية من مركب الألفا تربينيول أيضا عن إضافة الزيت العطرى فى المرحلة الأولى من الطور اللوغاريتمى و عند عملية إستخلاص الألفاتربينيول بإستخدام خليط من إيثير ثثائى الأثيل و البنتان (1 : 1). 